\title{
ANALISIS LIGNIN DAN STRUKTUR ANATOMI PLANLET TOMAT (Lycopersicum esculentum MILL) HASIL SELEKSI ASAM SALISILAT SECARA IN VITRO
}

\author{
ANALYSIS OF LIGNIN AND ANATOMY STRUCTURE OF TOMATO PLANTLET \\ (Lycopersicum esculentum MILL) RESULTS IN VITRO SALICYLIC ACID SELECTION
}

\author{
Endang Nurcahyani dan Lindawati \\ Jurusan Biologi FMIPA Universitas Lampung \\ Jurusan Biologi FMIPA Universitas Lampung \\ Jl. Soemantri Brojonegoro No.1, Bandar Lampung, Lampung, Indonesia, 35145
}

\begin{abstract}
Abstrak
Kajian tentang seleksi planlet tomat dengan asam salisilat konsentrasi $0,15,30,45$, dan $60 \mathrm{ppm}$ secara in vitro terhadap struktur anatomi dan lignifikasi, telah dilaksanakan di Laboratorium Kultur Jaringan, Jurusan Biologi, Fakultas MIPA,Universitas Lampung. Penelitian ini dilakukan dari bulan Juni sampai Agustus 2014. Data yang diperoleh selama seleksi dengan asam salisilat berupa data kualitatif dan data kuantitatif. Data kualitatif disajikan dalam bentuk deskriptif komparatif dan di dukung foto. Dalam penelitian ini digunakan rancangan acak lengkap dengan 6 ulangan. Analisis ragam dan uji BNT dilakukan pada taraf nyata $5 \%$. Hasil penelitian menunjukkan bahwa ketebalan lignin pada xilem batang planlet tomat yang diimbas asam salisilat pada konsentrasi 15,30 , dan $60 \mathrm{ppm}$ menunjukkan ketebalan yang lebih besar dibandingkan kontrol, sedangkan pada konsentrasi $45 \mathrm{ppm}$ ketebalannya lebih kecil dibandingkan kontrol. Struktur anatomi batang planlet tomat yang diimbas asam salisilat dibandingkan dengan kontrol terdapat perbedaan pada bagian epidermis, jari-jari empulur, dan kambium. Pada epidermis, jari-jari empulur, dan kambium batang yang diimbas asam salisilat mengalami lignifikasi.
\end{abstract}

Kata kunci: planlet tomat, lignin, struktur anatomi, asam salisilat, in vitro.

\begin{abstract}
Studies on the selection of tomato plantlets with salicylic acid concentrations of $0,15,30,45$, and 60 ppm in vitro against anatomical structures and analysis of lignin, has been carried out in the Tissue Culture Laboratory, Department of Biology, Faculty of Math and Sciences, University of Lampung. This research was conducted from June to August 2014. The data obtained during the selection with the salicylic acid in the form of quantitative and qualitative data. Qualitative data were presented in the form of comparative descriptive and supported the picturess. The study used a completely randomized design with six replications. Analysis of variance and LSD test was performed at $5 \%$ significance level. The results showed that the thickness of the lignin in the stem xylem tomato plantlets scanned salicylic acid at a concentration of 15,30 , and $60 \mathrm{ppm}$ showed a greater thickness than control groups, whereas at concentrations of $45 \mathrm{ppm}$ thickness was smaller than the control. Anatomical structures stem of tomato plantlets were scanned salicylic acid compared with controls andicated some differences in the epidermis, the radius of the pith, and cambium. In the epidermis, the radius of the stem cambium pith and salicylic acid scanned underwent lignification (lignified).

Keywords: tomato plantlets, lignin, anatomical structure, salicylic acid, in vitro.
\end{abstract}

\section{PENDAHULUAN}

Tomat (Lycopersicum esculentum Mill) merupakan salah satu komoditas hortikultura yang memiliki nilai ekonomi yang tinggi dan masih memerlukan penanganan yang serius dalam hal untuk meningkatkan hasil dan kualitas buah tomat. Produksi tomat di Indonesia rata-rata masih rendah, yaitu 6,3 ton/ha apabila dibandingkan dengan negaranegara seperti Taiwan, Saudi Arabia, dan India dengan hasil produksinya adalah 21 ton/ha, 13,4 ton/ha, dan 9,5 ton/ha. Salah satu kendala dari rendahnya produksi tomat yang ada di Indonesia adalah pemberantasan penyakit yang kurang efisien terhadap infeksi mikroba patogen penyebab penyakit (Wasonowati, 2011). Mikroba patogen yang sering menyerang tanaman tomat adalah Fusarium oxysporum f.sp. lycopersici (Fol). Fol dapat menghambat pertumbuhan suatu 
tanaman, sehingga perlu adanya pencegahan (Soesanto dan Rahayuniati, 2009).

Salah satu alternatif cara pengendalian penyakit yang efisien, efektif, dan aman terhadap lingkungan, antara lain menggunakan varietas yang tahan atau resisten. Penggunaan varietas unggul yang tahan terhadap penyakit dengan daya hasil tinggi merupakan salah satu alternatif pengendalian penyakit yang penting dan tidak menimbulkan dampak negatif seperti penggunaan pestisida (Nurcahyani et al., 2012). Pengembangan kultivar tahan Fol tersebut dapat dilakukan antara lain dengan metode seleksi in vitro yaitu mengkulturkan eksplan berupa jaringan atau organ pada medium yang mengandung asam salisilat konsentrasi selektif (Suryanti, et al., 2009).

Asam salisilat (AS) merupakan signal penting dalam ketahanan tanaman, digunakan sebagai senyawa pengimbas ketahanan terhadap penyakit layu Fusarium pada tanaman pisang (Suryanti, et al., 2009), melon (Sujatmiko et al., 2012), jagung (Hoerussalam et al., 2013). Ketahanan terimbas merupakan ketahanan yang terekspresi setelah patogen menyerang (Huang, 2001). Beberapa parameter dapat menggambarkan terjadinya mekanisme ketahanan tanaman terhadap infeksi patogen antara lain peningkatan senyawa fenol, peningkatan enzim peroksidase termasuk kelompok Pathogenesis Related-protein (PRprotein), dan adanya lignifikasi (Vidhyasekaran, 1997; Agrawal et al., 1999; Lea \& Leegood, 1999).

Penelitian ini dilakukan untuk mengetahui dan menganalisis karakter ekspresi spesifik planlet tomat tahan asam salisilat secara in vitro meliputi lignifikasi dan struktur anatomi nya. Planlet tomat yang tahan asam salisilat nantinya apabila diregenerasikan menjadi tanaman dapat menghasilkan galur yang tahan terhadap infeksi Fol, dengan demikian diharapkan akan dapat meningkatkan kembali kualitas dan produksi tanaman tomat di Indonesia.

\section{BAHAN dan METODE}

Penelitian ini dilaksanakan di Laboratorium Kultur Jaringan, Jurusan Biologi, Fakultas Matematika dan IImu Pengetahuan Alam, Universitas Lampung dari bulan Juni sampai Agustus 2014.

Persiapan medium tanam dan seleksi.

Medium yang digunakan adalah Murashige \& skoog (MS) padat dengan penambahan ZPT (Zat Pengatur Tumbuh) BAP $1 \mathrm{mg} / \mathrm{L}$. Sterilisasi medium dengan menggunakan autoklaf pada tekanan $17,5 \mathrm{psi}, 121{ }^{\circ} \mathrm{C}$ selama 15 menit. Medium MS yang sudah disterilkan kemudian ditambah asam salisilat (AS) dengan konsentrasi $0 \mathrm{ppm}$ (kontrol), $15 \mathrm{ppm}, 30 \mathrm{ppm}$, $45 \mathrm{ppm}$, dan $60 \mathrm{ppm}$. Sebelum digunakan, medium ini di inkubasikan selama 7 hari pada suhu kamar $\left(25^{\circ} \mathrm{C}\right)$ untuk memastikan bahwa asam salisilat telah tersaring dengan baik. Apabila dalam waktu 7 hari tidak terjadi kontaminasi pada medium, maka medium dapat digunakan.

\section{Sterilisasi benih tomat yang akan ditanam}

Benih tomat dicuci dengan aquades dan dikocok, lalu dimasukkan ke dalam larutan chlorox $10 \%$ dikocok selama 10 menit. Benih dibilas dengan aquades. Benih kemudian ditanam pada medium MS yang sudah ditambah asam salisilat dan BAP. Penanaman benih dilakukan di dalam LAF Cabinet. Setiap botol kultur ditanami 3 benih, sehingga total benih yang ditanam sebanyak 150 dalam 50 botol kultur. Benih-benih tomat tersebut dikecambahkan pada medium MS sampai terbentuk planlet. Inkubasi kultur dilakukan pada ruangan dengan penyinaran \pm 1000 lux, $24 \mathrm{jam} /$ hari dan suhu $\pm 20 \stackrel{\circ}{\circ}$.

\section{Analisis lignin}

Pengamatan lignifikasi pada irisan melintang batang planlet tomat menggunakan metode Ruzin (1999). Planlet tomat dicabut kemudian batangnya dibersihkan dari sisa agar. Batang yang sudah bersih difiksasi dengan cara direndam dalam FAA dan disimpan selama 24 jam. Batang selanjutnya dijepit dibagian tengah gabus, dan diiris dengan sliding microtom secara melintang dengan ketebalan 5-10 $\mu \mathrm{m}$. Potongan irisan melintang direndam dalam safranin encer $(1 \% \mathrm{w} / \mathrm{v})$ selama $1,5 \mathrm{jam}$, kemudian dibilas dengan akuades. Potongan batang yang telah dibilas direndam dalam larutan alkohol konsentrasi $70 \%$ selama $2-5$ menit kemudian direndam dalam safranin dan dikering-anginkan. Sesudah kering, potongan batang diletakkan di atas gelas preparat dan ditutup dengan gelas penutup. Selanjutnya gelas preparat diamati di bawah mikroskop dengan perbesaran 400 kali. Jaringan batang yang terlignifikasi akan tampak berwarna merah muda. Pengaruh asam salisilat, selanjutnya dideteksi efeknya antara lain melalui pengukuran ketebalan lignin pada dinding xilem. Pengukuran ketebalan lignin dengan menggunakan mikrometer okuler.

\section{Analisis anatomi jaringan batang}

Pembuatan preparat awetan penampang melintang batang planlet tomat menurut Ruzin (1999). Batang planlet tomat difiksasi menggunakan larutan alkohol $70 \%$. Setelah itu 
dilakukan pengirisan melintang batang dengan menggunakan sliding microtom, ketebalan 2030 mikrometer. Irisan ditampung dalam Petridish yang diberi alkohol $70 \%$. Lalu dilanjutkan pewarnaan dengan safranin $1 \%$ dan di bilas menggunakan akuades, kemudian ditambahkan anilin blue dalam alkohol $70 \%$ selama 24 jam. Kemudian preparat diletakkan di atas gelas benda, ditutup dengan gelas penutup yang sebelumnya diberi balsam kanada. Preparat dikeringkan di atas hot plate dengan suhu $45 \stackrel{\circ}{\mathrm{C}}$ hingga balsam kanada mengering. Terakhir dilakukan pemberian nama disebelah kiri gelas penutup dengan melekatkan etiket yang diberi keterangan nama spesies.

\section{Rancangan Percobaan dan Analisis Data}

Penelitian dilaksanakan dalam rancangan acak lengkap dengan 5 perlakuan dan 6 ulangan. Perlakuan adalah penambahan asam salisilat ke dalam medium MS (Murashige \& Skoog) dengan konsentrasi 0 ppm (kontrol), 15 ppm, 30 ppm, 45 ppm, dan 60 ppm. Satuan percobaan adalah planlet tomat yang ditanam pada medium MS. Data yang diperoleh selama seleksi dengan AS berupa data kualitatif dan data kuantitatif. Data kualitatif disajikan dalam bentuk deskriptif komparatif dan didukung foto. Data kuantitatif dari setiap parameter dianalisis dengan menggunakan Analisis Ragam (Analysis of Variance) atau Anova. Analisis ragam atau anova dilakukan pada taraf nyata $5 \%$ dan uji lanjut dengan uji BNT pada taraf nyata $5 \%$.

\section{HASIL dan PEMBAHASAN}

\section{A. Lignifikasi}

Parameter yang dapat menunjukkan terjadinya mekanisme ketahanan planlet tomat hasil pengimbasan asam salisilat adalah terjadinya lignifikasi pada jaringan berkas pengangkut. Penambahan tebal lignin pada dinding xilem telah di amati pada batang planlet tomat yang di imbas asam salisilat (konsentrasi 15 ppm, 30 ppm, 45 ppm, dan 60 ppm) dan kontrol. Menurut Bouizgarne et al., (2006), pembentukan lignin melibatkan peran enzim peroksidase. Peroksida merupakan pendonor enzim peroksidase untuk pembentukkan lignin. Peroksida yang meningkat akan meningkatkan pula aktivitas enzim peroksidase yang berperan dalam pembentukan lignin.

Berdasarkan pengamatan, lignin terbentuk hampir pada semua perlakuan, oleh karena itu pengaruh perlakuan cekaman asam salisilat bisa dideteksi efeknya melalui pengukuran ketebalan lignin pada dinding xilem (Tabel 1).
Tabel 1. Rata-rata ketebalan lignin $(\mu \mathrm{m})$ pada xilem planlet tomat yang tidak diimbas (kontrol) dan diimbas asam salisilat $(15,30,45$, dan 60 ppm).

\begin{tabular}{cc}
\hline Perlakuan & $\begin{array}{c}\text { Rata-rata ketebalan } \\
\text { lignin }(\mu \mathrm{m})\end{array}$ \\
\hline $0 \mathrm{ppm}$ & $3,33 \pm 0.210^{\mathrm{a}}$ \\
$15 \mathrm{ppm}$ & $4,16 \pm 0.166^{\mathrm{b}}$ \\
$30 \mathrm{ppm}$ & $4,00 \pm 0.258^{\mathrm{b}}$ \\
$45 \mathrm{ppm}$ & $2,50 \pm 0.255^{\mathrm{c}}$ \\
60 ppm & $4,66 \pm 0.333^{\mathrm{b}}$ \\
\hline Keterangan : Angka yang diikuti oleh huruf yang sama \\
tidak berbeda nyata pada taraf $5 \%$
\end{tabular}

Tabel 1 menunjukkan adanya peningkatan ketebalan lignin pada dinding sel xilem pada perlakuan $15 \mathrm{ppm}, 30 \mathrm{ppm}$ dan $60 \mathrm{ppm}$ dibandingkan kontrol, sedangkan pada konsentrasi $45 \mathrm{ppm}$ mengalami penurunan dibandingkan kontrol. Hal ini menunjukkan bahwa planlet memberi tanggapan ketahanan melalui penambahan tebal lignin setelah diperlakukan dengan asam salisilat. Sistem ketahanan tanaman tergantung pada interaksi inang, patogen, dan lingkungan.

Lignifikasi yang terjadi pada dinding epidermis akar pada penelitian ini didukung oleh penelitian De Ascensao \& Dubery (2000), yang mengutarakan bahwa lignifikasi terjadi pada dinding sel epidermis akar pisang yang diinfeksi Fusarium oxysporum f. sp. cubense. Selain itu $\mathrm{He}$ et al., (2002), mengemukakan bahwa kandungan lignin akar Asparagus officinals yang resisten mengalami peningkatan setelah di inokulasi dengan Fusarium oxysporum f. sp asparagi. Hammerschmidt \& Dann (1985) menyatakan pula bahwa pada dinding sel epidermis daun mentimun (Cucumis sativus L.), melon (Cucumis melo L.) dan semangka (Citrullus vulgaris Schrad) terjadi lignifikasi setelah diinokulasi dengan spora jamur Colletotrichum lagenarium (Pass).

\section{B. Analisis Anatomi Jaringan Batang}

Analisis anatomi jaringan batang dilakukan dengan mengamati perbedaan anatomi batang planlet tomat yang tahan terhadap pengimbasan asam salisilat dan kontrol. Berdasarkan pengamatan, struktur anatomi batang planlet tomat pada umumnya tersusun atas epidermis, korteks dan stele (berkas vaskuler dan empulur). Berdasarkan pengamatan, struktur anatomi batang planlet tomat tersusun atas epidermis, korteks, floem, kambium, jari-jari empulur, xilem, dan empulur. Hasil pengamatan epidermis batang terdiri atas selapis sel dan tersusun rapat tanpa adanya ruang antar sel. Pada planlet tomat tahan asam salisilat, dinding sel epidermis lebih tebal dari 
pada kontrol, demikian pula pada jari-jari empulur dan kambiumnya (Gambar 1).

Menurut Bouizgarne et al. (2006) penambahan asam salisilat pada konsentrasi non-toksik mengakibatkan peningkatan dan pengaktifan $\mathrm{O}_{2}$ dan $\mathrm{H}_{2} \mathrm{O}_{2}$. Aktivitas $\mathrm{H}_{2} \mathrm{O}_{2}$ berhubungan dengan peroksidase dalam pembentukan lignin. $\mathrm{H}_{2} \mathrm{O}_{2}$

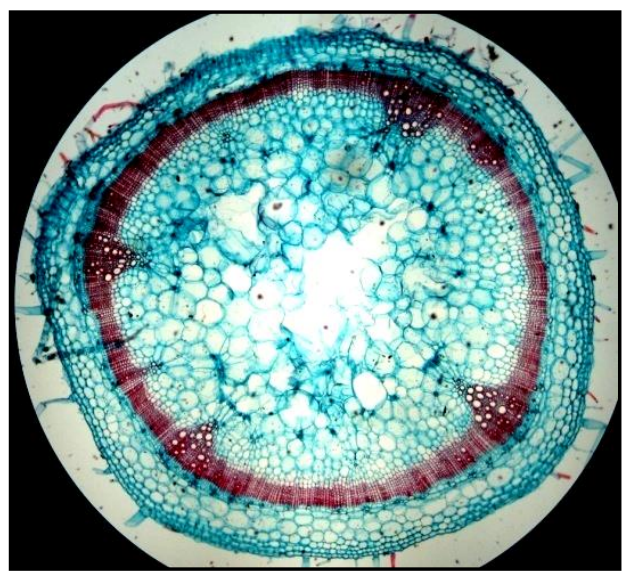

merupakan pendonor peroksidase untuk pembentukan lignin. Penampang melintang anatomi batang tomat, memperlihatkan struktur umum penyusun batang tomat dan penebalan epidermis, jari-jari empulur serta kambium disajikan pada Gambar 1 dan 2.

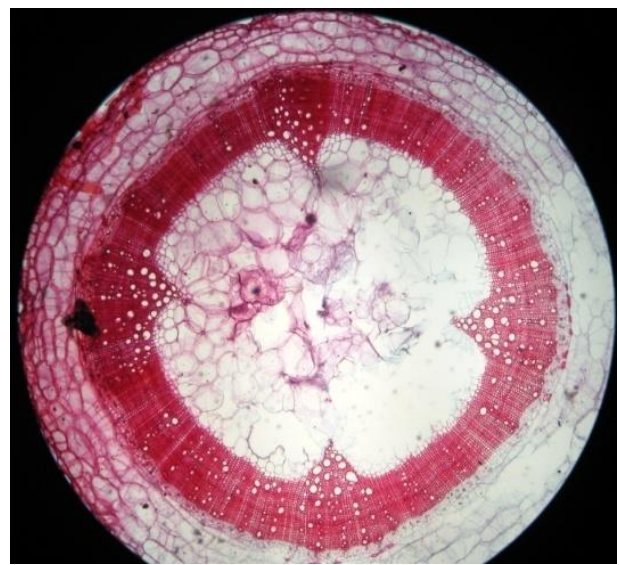

Gambar 1. Penampang melintang anatomi batang planlet tomat, memperlihatkan struktur umum penyusun batang planlet. (kanan) Konsentrasi asam salisilat 0 ppm, (kiri) konsentrasi asam salisilat 60 ppm. (Ep) epidermis, (em) empulur, (FI) Floem, (JE) jari-jari empulur, (kor) korteks, (kb) kambium, (xy) xylem.
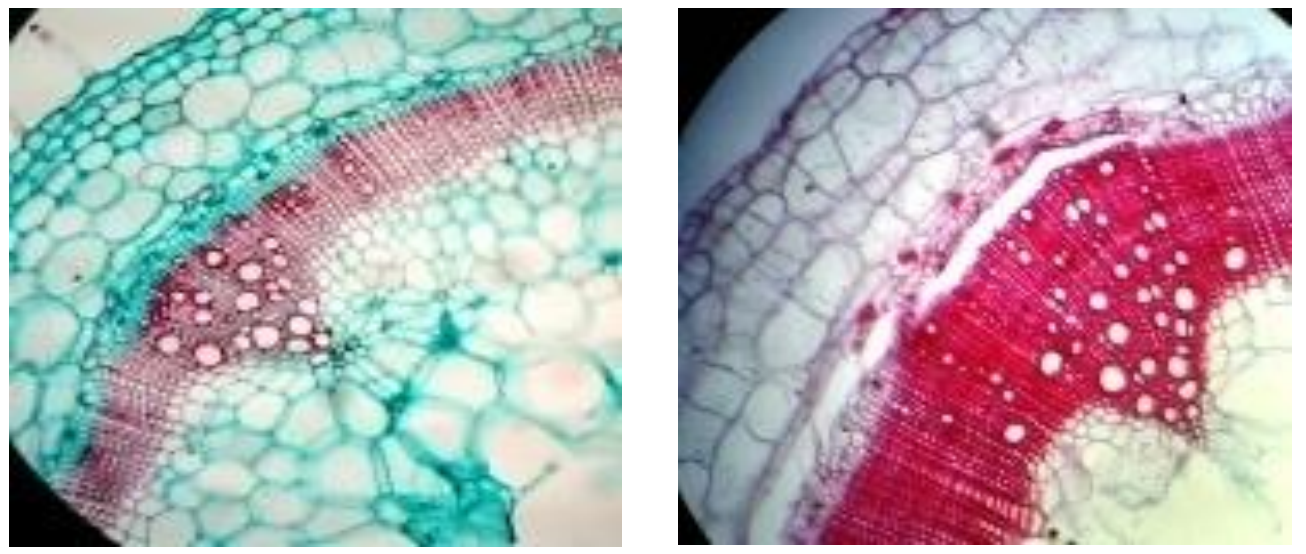

Gambar 2. Penampang melintang anatomi batang planlet tomat yang menunjukkan penebalan epidermis, jari-jari empulur dan kambium. A. berkas pengangkut konsentrasi 0 ppm, B. berkas pengangkut konsentrasi 60 ppm. (Ep) epidermis, (kb) kambium, (JE) jari-jari empulur.

\section{KESIMPULAN}

a. Lignin yang terdapat pada xilem batang planlet tomat yang diimbas asam salisilat pada konsentrasi 15, 30, dan 60 ppm menunjukkan ketebalan yang lebih besar dibandingkan control.

b. Analisis anatomi batang planlet tomat yang diimbas asam salisilat dengan batang planlet tomat yang tidak diimbas terdapat perbedaan pada bagian epidermis, jari-jari empulur, dan kambium. Pada epidermis, jari-jari empulur dan kambium batang yang diimbas asam salisilat mengalami penebalan dibandingkan kontrol.

\section{DAFTAR PUSTAKA}

Agrawal, A.A., S. Tuzun,S., and E. Bent. 1999. Induced Plant Defenses Againts Phatogens and Herbivores, Biocemistry, Ecology, and Agryculture. APS Press, St. Paul. Minessota. 390p.

Bouizgarne, B, HEM. Bouteau, C. Frankart, D. Reboutier, K. Madiona, AM. Pennarun, M. Monestiez, J. Trouverie, Z. Amiar, J. Briand, M. Brault, JP. Rona, Y. Ouhdouch, and El. Hadrami. 2006. Early Physiological Responses of Arabidopsis thaliana Cells to Fusaric Acid : Toxic and Signallling Effects. New Phytologist 169: 209 - 218. 
De Ascensao, A. R. D. C. F., and I.A. Dubery. 2000. Panama disease: Cell wall reinforcement in banana roots in response to elicitors from Fusarium oxysporum f. sp. cubense race fuor. Phytopathology 90:1173-1180.

Hammerschimdt, R. \& E.K. Dann. 2000.Induced Resistance to Disease. Environmentally Safe Approach to Crop Disease Control. Chapter 8. Lewish Publishers, Boca Raton. 177-194.

He CY, T. Hsiang, and DJ. Wolyn. 2002. Induction of Systemic Disease Resistance and Pathogen Defence Responses in Asparagus officinalis Inoculated with Pathogenic Strains of Fusarium oxysporum. Plant Pathology 51: 225-230

Hoerussalam, A. Purwantoro, dan A. Khaeruni. 2013. Induksi Ketahanan Tanaman Jagung (Zea Mays L.) Terhadap Penyakit Bulai Melalui Seed Treatment Serta Pewarisannya Pada Generasi S1. IImu Pertanian Vol. $16: 42-59$.

Huang, J.S. 2001. Plant Patogenesis and Resistence, Biochemisrty and Physiology of Plant-Microbe Interactions. Kluwer Academic Publisher. Dordrecht.

Lea,P. and R.C. Leegood. 1999. Plant Biocemistry and moleculer Biology. $2^{\text {nd }}$ ed. John Wiley \& Sons Ltd. Chichester.364 p.

Nurcahyani E, I. Sumardi, B. Hadisutrisno, dan E. Suharyanto. 2012. Penekanan
Perkembangan Penyakit Busuk Batang Vanili (Fusarium oxysporum f. sp. vanillae) Melalui Seleksi Asam Fusarat Secara In Vitro. J. HPT Tropika Vol.12 No.1: 12-22.

Soesanto,L dan R.F. Rahayuniati. 2009. Pengimbasan Ketahanan Bibit Pisang Ambon Terhadap Penyakit Layu Fusarium dengan Beberapa Jamur Antagonis. J.HPT Tropika.Vol 9. No 2; pp 130-140.

Sujatmiko,B., E. Sulistyaningsih, dan H.R. Murti. 2012. Studi Ketahanan Melon (Cucumis Melo L) Terhadap Layu Fusarium Secara In-Vitro dan Kaitannya Dengan Asam Salisilat. IImu Pertanian Vol. 15 pp 1 -18.

Suryanti, Y.D. Chinta, dan D. Sumardiyono. 2009. Pengimbasan Ketahanan Pisang TerhadapPenyakit Layu Fusarium Dengan Asam Salisilat In Vitro. Jurnal Perlindungan Tanaman Indonesia 15(2):pp 90-95.

Vidhyasekaran.P. 1997. Fungal Pathogenisis in Plants and Crops, Molecular Biology and Host Defense Mechanism. Marcell Dekker. New York. 553p.

Wasonowati, C. 2011. Menigkatkan pertumbuhan tanaman tomat ( Lycopersicum esculentum Mill) dengan sistem budidaya hidroponik. Agrovigor volume 4. pp 21-28. 